\title{
ANALISIS PENGUASAAN KONSEP DAN KETERAMPILAN BERPIKIR KREATIF SISWA SD MELALUI PROJECT BASED LEARNING
}

\author{
oleh: \\ Wa Ode Lidya Arisanti ${ }^{1}$, Wahyu Sopandi, Ari Widodo \\ Universitas Pendidikan Indonesia
}

\begin{abstract}
Learning science is not just memorize the concepts, but learn how to process and mastery of the scientific attitude. Actually, learning is still centered on the teacher, so that students can develop the knowledge and skills of thinking. Knowledge and thinking skills students can experience a change in the proper way, one way that can be done by applying the model of project-based learning. This study aims to determine whether there is a difference mastery of concepts and creative thinking skills between classes that implement learning model project based learning and classroom rather than project-based learning on water recycling materials. The research design used in this study was Quasi Experimental Design devoted no pattern Nonequivalent Control Group Design This design consists of two groups: the experimental group and the control group. Furthermore, each class were given a pretest and posttest study with mastery test questions using the concept of multiple choice questions of 15 questions and test creative thinking skills with five essay questions on each test. Classroom learning experiment treated with a model project based learning and classroom learning with no control got projet models based learning. The results showed in general there are significant differences in mastery of concepts $(p=0.00)$ between the experimental class learning by applying the model of project-based learning in the learning process (the average $\mathrm{N}$-gain $=0.477$ ) in the medium category, with students learning by applying rather than project-based learning (the average $\mathrm{N}$-gain $=0.290$ ) in the low category. There is no difference in the ability to think creatively $(p=0.22)$ between the experimental class and control class, with an average $\mathrm{N}$-gain the experimental class 0,075 while the control class is 0.060 which both are in the low category.
\end{abstract}

Keywords: project based learning, mastery of concepts, creative

\begin{abstract}
Abstrak: Belajar IPA bukan hanya menghafal konsep-konsep, akan tetapi belajar bagaimana proses dan penguasaan sikap ilmiah. Kenyatanyaan pembelajaran masih berpusat pada guru, sehingga siswa tidak dapat mengembangkan pengetahuan dan keterampilan berpikirnya. Pengetahuan dan keterampilan berpikir siswa dapat mengalami perubahan dengan cara yang tepat, salah satu cara yang dapat dilakukan dengan menerapkan model project based learning. Penelitian ini bertujuan untuk mengetahui ada tidaknya perbedaan penguasaan konsep dan keterampilan berpikir kreatif antar kelas yang menerapkan model pembelajaran project based learning dan kelas yang bukan project based learning pada materi daur air. Desain penelitian yang digunakan dalam penelitian ini adalah Quasi Experimental Design yang dikhususkan ada pola Nonequivalent Control Group Design Rancangan ini terdiri dari dua kelompok yakni kelompok eksperimen dan kelompok kontrol. Selanjutnya masingmasing kelas penelitian diberi pretest dan posttest dengan soal tes penguasan konsep menggunakan soal pilihan ganda sebanyak 15 soal dan tes keterampilan berpikir kreatif dengan 5 soal essay pada setiap tes. Kelas eksperimen diberi perlakuan pembelajaran dengan model project based learning dan kelas kontrol mendapat pembelajaran dengan bukan model projet based learning. Hasil penelitian menunjukan secara umum terdapat perbedaan penguasaan konsep yang signifikan $(\mathrm{p}=0,00)$ antara kelas eksperimen yang belajar dengan menerapkan model project based learning pada proses pembelajarannya (rata-rata $\mathrm{N}$-gain $=0,477$ ) pada kategori sedang, dengan siswa yang belajar dengan menerapkan bukan project based learning (rata-rata N-gain $=0,290$ ) pada kategori rendah. Tidak ada perbedaan kemampuan berpikir kreatif $(\mathrm{p}=0,22)$ antara kelas eksperimen dan kelas kontrol, dengan ratarata $\mathrm{N}$-gain pada kelas eksperimen 0,075 sedangkan pada kelas kontrol sebesar 0,060 yang mana keduanya berada pada kategori rendah.
\end{abstract}

Kata kunci: project based learning, penguasan konsep, kreatif

\footnotetext{
${ }^{1}$ Mahasiswa SPs UPI Bandung, Email: lidyaarisanti@gmail.com

2 Dosen Universitas Pendidikan Indonesia, Email: wsopandi@upi.edu
} 


\section{PENDAHULUAN}

Ilmu Pengetahuan Alam (IPA) berhubungan dengan cara mencari tahu tentang alam secara sistematis, sehingga IPA bukan hanya penguasan kumpulan pengetahuan yang berupa fakta, konsepkonsep atau prinsip-prinsip saja tetapi juga merupakan suatu proses penemuan (Iskandar, 1997). Dengan belajar IPA siswa belajar bagaimana fakta, konsep atau prinsip diperoleh dengan menerapkan metode dan sikap ilmiah yang kemudian diterapkan dalam kehidupan sehari-hari. Pendidikan IPA diharapkan dapat menjadi awal bagi siswa mempelajari dirinya sendiri dan alam sekitar, serta prospek pengembangan lebih lanjut dalam menerapkannya dalam kehidupan seharihari. Pendidikan IPA sebagai bagian dari pendidikan umum memiliki peranan penting khususnya dalam menghasilkan siswa yang mampu berpikir kritis, kreatif, logis, dan berinisiatif dalam menghadapi perkembangan ilmu pengetahuan/sains dan teknologi

Tujuan pendidikan IPA untuk anak SD seperti yang diungkapkan oleh Harlen (2000) adalah keterampilan dan konsep yang memungkinkan pemahaman tentang aspek ilmiah dari dunia sekitar. Jika melihat tujuan yang di sampaikan Harlen, idealnya proses pembelajaran IPA bukan hanya bagaimana siswa menguasai konsep akan tetapi dalam prosesnya siswa harus memiliki keterampilan mengidentifikasi dan menafsirkan. Sejalan dengan itu Bundu (2006) menyatakan bahwa pembelajaran IPA di SD hendaknya memiliki hasil belajar yaitu penguasaan produk ilmiah, penguasaan proses ilmiah, penguasaan sikap ilmiah dan hasil belajar IPA. Akan tetapi kenyataannya menurut Arends (1997) dalam Trianto (2009) mengungkapkan bahwa guru mengajar selalu menuntut siswa untuk belajar dan jarang memberikan pelajaran tentang bagaimana siswa untuk belajar, guru juga menuntut siswa untuk menyelesaikan masalah, tapi jarang mengajarkan siswa bagaimana seharusnya menyelesaikan masalah. Berdasarkan hasil observasi yang dilaksanakan pada bulan Oktober 2013, guru dalam proses pembelajarannya masih dilakukan secara konvensional yaitu pembelajaran masih berpusat pada guru, siswa mendengar, mencatat dan kemudian siswa menghafal. Di sisi lain, Indonesia menurut hasil studi Programme for Internasional Student Assessment (PISA) 2013 menepati urutan ke 64 dari 65 negara anggota PISA, dalam survei ini ada tiga kemampuan siswa yang dinilai yaitu kemampuan matematika, kemampuan membaca dan kemampuan ilmiah (sains). Sedangkan, hasil survei Trends in International Mathematics and Science Study (TIMSS) tahun 2011 yang diselenggarakan oleh Global Institute, diketahui bahwa indonesia menepati peringkat 38 dari 42 negara dalam bidang matematika dan peringkat ke 40 dari 42 negara dalam bidang sains. Selain itu berdasarkan hasil penelitian yang diungkapkan Ayan (2002) kreativitas akan mulai terkekang ketika anak mulai memasuki usia SD karena dalam pendidikan tradisional siswa harus duduk berderet atau berkelompok dua puluh hingga tiga puluh siswa dan diharuskan tunduk pada peraturan dan prosedur yang kaku dan kebanyakan membatasi keterampilan berpikir kreatif.

Berdasarkan hasil observasi dan data yang dipaparkan di atas menunjukan bahwa siswa kurang didorong untuk mengembangkan keterampilan berpikirnya. Akibatnya anak hanya mampu mengingat apa yang dipelajarinya dan tidak mengetahui bagaimana pengetahuan itu dapat diaplikasikan. Hal ini juga terlihat dalam kehidupan sehari-hari siswa, dimana siswa menjadi konsumtif dan tidak mengetahui bagaimana mencipta. Berdasarkan fakta tersebut terlihat bagaimana siswa tidak mampu mengembangkan konsep yang telah diberikan dan keterampilan berpikirnya. Penguasaan konsep yang dimaksud adalah kemampuan siswa dalam memahami IPA secara ilmiah, baik konsep secara teori 
maupun penerapannya dalam kehidupan sehari-hari sehingga siswa mampu membawa suatu konsep dalam bentuk lain yang tidak sama dengan dalam buku teks Bundu (2006).

Diperlukan usaha merubah pembelajaran yang hanya membuat siswa hanya mendengarkan dan menghafalkan saja, menjadi proses pembelajaran yang menantang untuk mengembangkan kemampuan berpikirnya. Salah satu cara yang dapat dilakukan adalah belajar dengan memecahkan masalah karena dalam belajar memecahkan masalah selain melatih siswa untuk menghubungkan konsep yang dimiliki dengan kehidupan nyata, selain itu siswa dituntut untuk mampu mengembangkan keterampilan berpikirnya untuk menyelesaikan masalah yang dihadapinya. Agar siswa dapat memiliki kemampuan seperti yang disyaratkan dalam tujuan pengembangan kurikulum 2013 guru sebagai ujung tombak keberhasilan pendidikan dan terlibat langsung dalam pembelajaran, dituntut untuk mampu mengembangkan pembelajaran yang dapat menggali kemampuan siswa dalam mengembangkan penguasaan konsep dan keterampilan berpikir kreatif. Salah satu model pembelajaran yang disarankan untuk digunakan dalam penerapan kurikulum 2013 adalah project based learning atau yang dalam kurikulum 2013 disingkat PjBL. PjBL memungkinkan siswa tidak hanya mengembangkan keterampilan intelektualnya, akan tetapi keterampilan manualnya juga dapat berkembang. Seperti yang diungkapkan oleh Jhon Dewey (dalam Iskandar, 1997) mengungkapkan learning by doing, maksudnya adalah siswa belajar sesuatu melalui kegiatan manual.

Pembelajaran berbasis proyek merupakan model pembelajaran yang inovatif. Dengan pembelajaran berbasis proyek siswa dengan bantuan guru tidak hanya mengumpulkan informasi-informasi, tapi mereka juga harus menggunakan kemampuan berfikir dan penalaran mereka, untuk memahami informasi sehingga membentuk konsep-konsep mereka sendiri dan kemudian menunjukan, dalam pemecahan masalah, sebuah jawaban atas pertanyaan atau membuat desain baru sendiri. Fokus dalam PjBL terletak pada konsep-konsep dan prinsip-prinsip inti dari disiplin ilmu, melibatkan pembelajaran dalam investigasi pemecahan masalah dan kegiatan tugas-tugas bermakna yang lain, memberi kesempatan belajar bekerja secara otonom mengkonstruksi pengetahuan mereka sendiri, dan menciptakan produk nyata (Thomas, 2000). Project based learning menuntut siswa untuk mengembangkan pengetahuan konsep dan keterampilan berpikir kreatif, sesuai dengan perinsip belajar sepanjang hidup yang mengacu pada empat pilar pendidikan universal, yaitu belajar untuk mengetahui (learning to know), belajar dengan melakukan (learning to do), belajar untuk hidup dalam kebersamaan (learning to live together) dan belajar menjadi diri sendiri (learning to be).

Banyak penelitian telah dilakukan berkaitan penerapan $\mathrm{PjBL}$ untuk melihat efektivitas PjBL diantaranya: A Review Of The Research dari Thomas (2000) mengungkapkan dalam studinya menemukan beberapa bukti bahwa pendekatan project based learning meningkatkan kualitas belajar siswa dibandingkan dengan model pembelajaran lain. Pendekatan project based learnig efektif untuk proses mengajar seperti pemecahan masalah dan pengambilan keputusan. Penelitian Egenrieder (2010) dari hasil penelitiannya menunjukan bahwa PjBL dapat menumbuhkan kemandirian siswa dalam menumbuhkan minat belajar dan berkarir di bidang STEM (Science, Technology, Ergineering dan Mathematics). Penelitian lain dilakukan Boaler (dalam Bellanca, 2012) yang melakukan studi selama tiga tahun di dua sekolah menengah di Inggris mencatat perbedaan penting dalam pemahaman siswa tentang data prestasi matematika. Dimana Boaler menemukan bahwa siswa dalam sekolah berbasis proyek memiliki hasil yang lebih baik dibandingkan sekolah 
yang lebih tradisional dalam memahami konsep dan menganalisis masalah matematika dengan nilai perbandingan 3:1. Penelitian yang dilakukan Kwon dkk (2014) penelitian ini dilakukan utnuk meningkatkan kualitas sekolah dengan menerapkan proyek dengan disain dari berbagai bidang ilmu.

Penelitian lain dilakukan oleh Andriana (2012) pada siswa SD menunjukan kemampuan kerja ilmiah dan penguasaan konsep siswa yang menerpkan pembelajaran PjBL mengalami peningkatan yang lebih baik dibandingkan kelas yang menerapkan pembelajaran konvensional. Penelitian lain Heryadi (2012) yang dilakukan pada siswa SMA menunjukan bahwa kelas yang menerapkan PjBL dalam proses pembelajarannya menguasai konsep lebih baik daripada kelas konvensional. Sedangkan penelitian dilakukan oleh Azis (2014) kelas yang menerapkan $\mathrm{PjBL}$ memiliki peningkatan keterampilan proses sains dan keterampilan berpikir kritis yang lebih baik dibandingkan dengan kelas yang belajar secara konvensional. Dalam penelitian ketiganya proyek yang dikembangkan oleh siswa diarahkan oleh guru, oleh sebab itu penulis tertarik untuk melakukan penelitian dimana pada proses pembelajaran dengan menerapkan $\mathrm{PjBL}$ guru memberikan kebebasan untuk menentukan pertanyaan yang akan dikembangkan menjadi proyek dan menentukan sendiri proyek yang akan dikembangkan oleh siswa. Hal tersebut dilakukan dengan harapan siswa dapat menguasai konsep dan mengembangkan keterampilan berpikir kreatifnya dengan lebih baik. Berdasarkan uraian di atas penulis mengajukan sebuah studi dengan judul "Analisis Penguasaan Konsep dan Keterampilan Berpikir Kreatif Siswa Sd Melalui Project Based Learning

\section{TINJAUAN TEORETIS}

\section{Project Based Learning}

Proyek seperti yang diungkapkan Roopnarine dan Johnson (2011) adalah penelitian sebuah topik yang diperluas dan mendalam yang idealnya merupakan topik yang layak bagi perhatian, waktu dan energi anak-anak. Pendapat yang sama diungkapkan oleh Katz (dalam Clark, 2006) A project is an-depth investigation by children of a topic that is worthy of their time, attention, and energy. Dari kedua pendapat tersebut dapat disimpulkan bahwa proyek adalah pengkajian sebuah topik dari berbagai aspek yang dilakukan secara mendalam yang membutuhkan perhatian penuh dan membutuhkan waktu yang cukup lama.

Banyak definisi yang diungkapkan para ahli berkaitan dengan project based learning Knoll (1997) mengungkapkan:

"The Project is one of the standard teachings method. The children work their own, without help and interference from their teacher or direction from a formal lesson plan. The teacher prepare the lessons by selecting the subject matter and material and giving thought to what questions were to be asked, what discussions would be pursued, and what activities would be proposed."

Selanjutnya The George Lucas
Educational Foundation (2007)
mengungkapkan Project based
learning dirancang untuk digunakan pada permasalahan komplek yang diperlukan siswa dalam melakukan insvestigasi dan memahaminya. Melalui project based learning, proses inquiry dimulai dengan memunculkan pertanyaan penuntun (a guiding question) dan membimbing siswa dalam sebuah proyek kolaboratif yang mengintegrasikan berbagai subjek (materi) dalam kurikulum. Pada saat pertanyaan terjawab, secara langsung siswa dapat melihat berbagai elemen utama sekaligus berbagai prinsip dalam sebuah disiplin yang sedang dikajinya. Project based learning merupakan investigasi mendalam 
tentang sebuah topik dunia nyata, hal ini akan berharga bagi atensi dan usaha siswa

Menurut Boss \& Krauss (2007) project based learning adalah model yang dapat meningkatkan motivasi belajar dan mengembangkan kemampuan siswa dalam memecahkan masalah serta dapat mengembangkan kemampuuan berpikir tingkat tinggi, karena dalam proses pembelajarannya siswa melakukan investigasi terhadap pertanyaan terbuka dan mengaplikasikan pengetahuan mereka untuk membuat produk nyata.

Roopnarine dan Johnson (2011) mengungkapkan bahwa tujuan dari model project based learning adalah memberikan berbagai macam pengalaman di dalam kelas yang membentuk peran serta dalam proses demokratis: kerjasama, menyimak dan merespon ide satu sama lain, mengoordasikan upaya dan kontribusi yang berbeda dari anggota dan seluruh subkelompok, menyelesaikan perselisihan meraih kesepahaman bagaimana memecahkan masalah dan menyelesaikan tugas dan sebagainya. Pendapat lain diungkapkan Katz dan chard (1989) mengemukakan bahwa tujuan The Project Approach terdiri dari empat kategori 1. Memperoleh pengetahuan dan keterampilan, 2. Meningkatkan kompetensi sosial, 3. Mengembangkan disposisi atau karakter, dan 4. Mengembangkan perasaan berkaitan dengan pengalaman sekolah.

Dalam pandangan Killpatrick (dalam Knoll, 1997), proyek memiliki empat fase: pemaknaan, perencanaan, pelaksanaan, dan menilai. Lebih rinci Katz (dalam Clark, 2006) mengungkapkan:

"A Project involves three phases: Phase 1 : children and their teacher select and discuss a topic to be explored, Phase 2 : the children conduct firsthand investigation and then create representations of their findings. Phase 3 : culminating and debriefing events"

Langkah-langkah pembelajaran project based learning diungkapkan oleh The George Lucas Educational Foundation (2007); (a) Start with the essential question; (b) Design a plan for the project; (c) Create a schedule; (d) Monitor the students and the progress of the project; (e) Asses the outcome; (f) Evaluate the experience;.

\section{Penguasaan Konsep}

Menurut Anderson (2010) konsep adalah skema, model mental, atau teori implisit dan eksplisit. Skema berkaitan dengan bagaimana suatu pengetahuan dihubungkan satu sama lain. Sedangkan menurut Dahar (2011) konsep merupakan dasar bagi proses mental yang lebih tinggi untuk merumuskan prinsip dan generalisasi.

Konsep adalah kategori-kategori yang mengelompokan objek, kejadian dan karekteristik berdasarkan properti umum Zacks \& Tversky (Santrok, 2010). Sedangkan menurut Hahn \& Ramscar (Santrok, 2010) mengungkapkan konsep adalah elemen dari kognitif yang membantu menyederhanakan dan meringkas informasi.

Penguasaan konsep menurut Bundu (2006) siswa yang dianggap telah mengusai konsep adalah siswa yang dapat memberikan tanggapan terhadap pertanyaan/rangsangaan yang bervariasi pada kelompok atau kategori yang sama. Penguasaan konsep merupakan kemampuan siswa dalam memahami IPA secara ilmiah, baik konsep secara teori maupun penerapannya dalam kehidupan seharihari. Siswa dikatakan menguasai konsep apabila ia mampu mendefinisikan konsep, mengidentifikasi dan memberi contoh atau bukan contoh dari konsep, sehingga dengan kemampuan ini ia 
bisa membawa suatu konsep dalam bentuk lain yang tidak sama dengan dalam buku teks. Dengan penguasaannya seseorang siswa mampu mengenali prosedur atau proses menghitung yang benar dan tidak benar serta mampu menyatakan dan menafsirkan gagasan untuk memberikan alasan induktif dan deduktif sederhana baik secara lisan, tertulis atau mendemonstrasikan (BSNP, 2006).

Cara yang digunakan untuk mengukur tingkat penguasaan konsep siswa dilakukan dengan penerapan taksonomi Bloom dalam Aderson \& Krathwohl (2010) untuk mengukur proses kognitif siswa, adapun kategorikategori dalam dimensi proses kognitif siswa yaitu; (1) Mengingat, mengambil kembali pengetahuan dari memori jangka panjang. Aspek ini mengacu pada kemampuan mengenal dan mengingat materi yang sudah dipelajari dari yang sederhana sampai pada hal-hal yang sukar. (2) Memahami, mengkonstruksi makna dari materi pembelajaran, termasuk apa yang diucapkan, ditulis, dan digambar oleh guru. (3) Mengaplikasikan, menerapkan atau menggunakan suatu prosedur dalam keadaan tertentu. (4) Menganalisis, memecah-mecah materi jadi bagian-bagian penyusunannya dan menentukan hubungan-hubungan antarbagian itu dan hubungan antara bagian-bagian tersebut dan keseluruhan struktur dan tujuan. (5) Mengevaluasi, mengambil keputusan berdasarkan kriteria dan/atau standar. (6) Mencipta, memadukan bagianbagian untuk membentuk sesuatu yang baru dari koheren atau untuk membuat suatu produk yang orisinal.

Hasil belajar kognitif siswa dalam penelitian ini hanya ditinjau lima ranah kognitif yaitu mengingat, memahami, mengaplikasikan, menganalisis dan mengevaluasi karena disesuaikan dengan standar kompetensi (SK).
Konsep yang harus dikuasai siswa pada penelitian ini berkaitan dengan materi daur air yaitu: manfaat air dalam kehidupan, proses daur air, perubahan fisika yang terjadi pada proses daur air, pengaruh kegiatan manusia terhadap proses daur air, kegiatan manusia yang mempengaruhi kualitas air, pentingnya menghemat air dan cara yang dapat dilakukan untuk menghemat air.

\section{Keterampilan Berpikir Kreatif}

Santrock (2010) menyatakan bahwa berfikir adalah memanipulasi atau mengelola dan mentransformasi informasi dalam memori. Ini sering dilakukan untuk membentuk konsep, bernalar dan berfikir secara kritis, membuat keputusan, berfikir kreatif dan memecahkan masalah. Berdasarkan prosesnya berfikir dapat dikelompokkan dalam berfikir dasar dan berfikir kompleks. Proses berfikir kompleks yang disebut berfikir tingkat tinggi meliputi pemecahan masalah, pengambilan keputusan, berfikir kritis dan berfikir kreatif.

Kreativitas adalah kemampuan berpikir tentang sesuatu dengan cara baru dan tidak biasa dan menghasilkan solusi yang unik atas suatu problem (Santrock, 2010). Sedangkan menurut May (2004) kreativitas yaitu sebagai keindahan dangkal, dan disisi lain, bentuk autentiknya yaitu proses membawa sesuatu yang baru menjadi ada. Robinson dalam (Brookhart, 2010) mendefinisikan kreativitas sebagai suatu proses yang memiliki ide-ide asli yang memiliki nilai.

Selanjutnya menurut Supriadi (1994) Kreativitas didefinisikan secara berbeda-beda. Sedemikian beragam definisi itu, sehingga pengertian kreativitas bergantung pada bagaimana orang mendifinisikannya. "creating is a matter of definition". Tidak ada satu definisi pun yang dianggap dapat mewakili pemahaman yang beragam tentang kreativitas hal ini disebabkan oleh dua alasan. Pertama sebagai 
konstruk hipotesis kreativitas merupakan ranah psikologis yang kompleks dan multidimensional yang mengandung berbagai tafsiran yang beragam. Kedua definisi-definisi kreativitas memberikan tekanan yang berbeda-beda, bergantung dasar teori yang menjadi acuan pembuat difinisi.

Berdasarkan penekanannya, definisi-definsi kreativitas dapat dibedakan ke dalam dimensi person, proses, produk, dan press. Rhodes (Supriadi, 1994) menyebut keempat dimensi tersebut sebagai "the four $P$ 's of Creativity". Definisi kreativitsa yang menekankan dimensi person dikemukakan oleh Guilford (1950): "Creativity refers to the abilities that are characteristics of creative people”. Difinisi yang menekakan segi proses diajukan oleh Munandar (1977):

"Creativity is a process that manifests it self in fluency, in flexibility as well in originality of thinking”. Barron (1976) menekankan segi produk yaitu "the ability to bring something new into existence". Sementara Amabile (1983) mengemukakan "Creativity can be regarded as the quality of products or responses judged to be to be creative by appropriate observers".

May (2004) menyatakan menurut teori psikoanalisis kreativitas memiliki dua ciri khas. Pertama, reduktif artinya teori tersebut mempersempit krativitas pada proses-proses tertentu. Kedua teori tersebut pada umumnya membuat kreativitas semata-mata suatu ekspresi pola-pola neurotik. Definisi umum tentang kreativitas dilingkaran psikoanalisis adalah "regresi dalam pelayanan ego".

Berdasarkan analisis faktor Guilford (Kim, 2006) menemukan bahwa ada empat yang menjadi ciri kemampuan berpikir kreatif, yaitu kelancaran (fluency of thinking), keluwesan (flexibility), keaslian (originality), penguraiaan (elaboration), penyatuan kembali (redefinition). Torrance dalam Supriadi (1994) Torrance Test of Creative Thinking (TTCT), yang disusun oleh Paul Torrance. Mulanya berpikir kreativitas ini bernama Minnesota Test of Creative (MTCT). Ada empat indikator berpikir kreatif yang diukur melalui tes ini, yaitu: orisinalitas, fleksibelitas, kelancaran (fluency), dan elaborasi dalam konsep ini Torrance merekomendasikan teori ini bisa dipakai mulai dari Sekolah Dasar hingga Perguruaan Tinggi.

Secara garis besar indikator keterampilan berpikir kreatif yang akan diamati pada penelitian ini adalah siswa dapat memberikan banyak jawaban dalam menyelesaikan masalah, dapat mencari banyak alternatif jawaban yang berbeda, mampu melahirkan ungkapan atau jawaban yang baru dan tidak biasa, mampu membuat kombinasi yang tidak umum dan mampu memperkaya dan mengembangkan gagasan yang terjadi dilikgkungan sekitar yang berhubungan dengan daur air dan kegiatan manusia yang dapat mempengaruhi daur air.

\section{METODOLOGI PENELITIAN}

Bentuk penelitian ini adalah Quasi Experimental Design yaitu desain yang mempunyai kelompok kontrol, tetapi tidak dapat berfungsi sepenuhnya untuk mengontrol variabel-variabel luar yang mempengaruhi pelaksanaan (Sugiyono, 2009). Quasi Experimental Design yang dikhususkan kepada pola Nonequivalent Control Group Design karena baik kelompok kontrol maupun kelompok eksperimen tidak dipilih secara random (Sugiyono, 2009). Desain penelitian tersebut berbentuk:

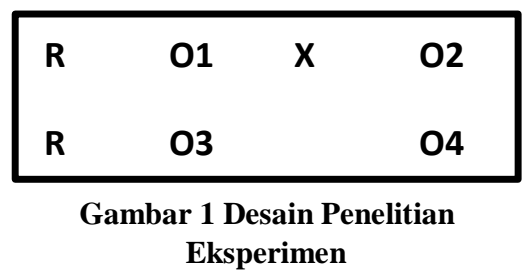


Keterangan:

R : Random

$\mathrm{X}$ : Perlakukan

O1 : Hasil pretest eksperimen sebelum perlakuaan

O2 : Hasil posttest eksperimen setelah perlakuan

O3 : Hasil pretest kontrol sebelum perlakuaan

O4 : Hasil posttest kontrol setelah perlakuan

Populasi dalam penelitian ini adalah siswa Sekolah Dasar Negri di Kab. Sumedang. Teknik pengambilan sampel pada penelitian ini dilakukan dengan teknik purposive sampling yaitu penetapan responden untuk dijadikan sampel berdsarkan kriteria-kriteria tertentu (Siregar, 2013). Penelitian ini dilaksanakan di SDN Sawahdadap I dan II di Kab. Sumedang dan yang menjadi subjek penelitian ini adalah siswa kelas $\mathrm{V}$ pada kedua SDN tersebut, dengan masingmasing jumlah siswa tiap kelas adalah 34 . Oleh karena itu sampel dalam penelitian ini adalah dua kelas dimana satu kelas sebagai kelas dengan menggunakan model project based learning dan satu kelas lainnya adalah kelas dengan menerapkan bukan project based learning dalam proses pembelajarannya

Analisis data dilakukan secara inferensial terhadap data kuantitatif. Data tersebut berupa data hasil tes penguasaan konsep dan tes berpikir kreatif dimana data tersebut diperoleh dari hasil pretest dan posttest yang berupa nilai. Pengujian statistik menggunakan bantuan software SPSS (Statistik Product adn Servis Solution) for windows v.20.0.

Teknik analisis data yang digunakan untuk mengetahui ada tidaknya perbedaan penguasaan konsep dan keterampilan berpikir kreatif antara kelas eksperimen dengan kelas kontrol adalah sebagai berikut:

a) Melakukan uji normalitas pada data nilai pretest dan posttest pada kedua kelompok, dengan melakukan uji
Shapiro-Wilk dengan taraf signifikansi 0,05 .

b) Selanjutnya dilakukan uji homogenitas untuk melihat variansi data pada kedua kelompok, uji yang dilakukan adalah uji Levene dengan taraf signifikansi 0,05.

c) Jika data yang diperoleh berdistribusi normal dan bervariansi homogen maka selanjutnya untuk uji hipotesis dilakukan uji t-test indevendent $_{\text {dua }}$ pihak (2-tailed), dengan menggunakan SPSS 20 untuk melihat perbedaan penguasaan konsep dan berpikir keratif antara kelas kontrol dan kelas eksperimen. adapun hipotesis statistik untuk uji ttest $_{\text {indevendent }}$ sebagai berikut:

$H_{0}: \mu_{1}=\mu_{2}$

$H_{1}: \mu_{1} \neq \mu_{2}$

Dengan syarat :

$H_{0}$ diterima bila, sig. (2-tailed) $\geq 0,05$, begitupun sebaliknya

$H_{1}$ diterima bila, sig. (2-tailed) $<0,05$, begitupun sebaliknya

d) Jika data yang diperoleh berdistribusi tidak normal dan bervariansi tidak homogen maka uji yang dilakukan adalah uji Mann Whitney.

Selain itu untuk melihat perbedaan peningkatan kompetensi pada sebelum dan sesudah dilakukan pembelajaran antara kelas kontrol dan kelas eksperimen dihitung pula $\mathrm{N}$-gain pada setiap indikator.

HASIL PENELITIAN DAN PEMBAHASAN

1. Penguasaan Konsep Siswa yang Menerapkan Project Based Learning dan yang Bukan Project Based Learning

Sebelum melaksnakan pemebelajaran kedua kelas melakukan pretest dengan mengunakan 15 soal untuk mengukur penguasaan konsep siswa, data yang dikumpulkan selanjutnya dihitung. Berikut ini hasil pengolahan data pretest penguasaan konsep pada kedua kelas: 
Tabel 2. Hasil Pengolahan Data Pretest Penguasaan Konsep

\begin{tabular}{|l|l|l|}
\hline \multirow{2}{*}{\multicolumn{1}{c|}{ Data }} & \multicolumn{2}{c|}{ Kelas } \\
\cline { 2 - 3 } $\mathrm{N}$ & Eksperimen & Kontrol \\
\hline Nilai Rata-rata & 34 & 34,03 \\
\hline Std. Deviasi & 11,66 & 34,51 \\
\hline Sig. Normalitas & 0,08 & 12,00 \\
\hline $\begin{array}{l}\text { Sig. } \\
\text { Homogenitas }\end{array}$ & 0,626 \\
\hline $\begin{array}{l}\text { Uji t-test } \\
\text { indevendent } \\
\text { Sig. (2-tailed) }\end{array}$ & 0,223 \\
\hline
\end{tabular}

Berdasarkan tabel di atas menunjukan bahwa nilai penguasan konsep pada kelas eksperimen dan kelas kontrol, berdistribusi normal dan bervariansi homogen oleh sebab itu uji yang dilakukan untuk mengambil keputusan adalah uji Uji t-test ${ }_{\text {indevendent }}$ Sig. (2-tailed). Dari hasil uji-t menunjukan bahwa tidak ada perbedaan yang signifikan penguasaan konsep siswa pada kelas eksperimen dan kelas kontrol, oleh sebab itu selanjutnya yang dianalisis adalah data nilai posttest. Berikut ini tabel data hasil pengolahan nilai posttest penguasaan konsep siswa pada kelas eksperimen dan kelas kontrol:

Tabel 1. Hasil Pengolahan Data Posttest Penguasaan Konsep

\begin{tabular}{|l|l|l|}
\hline \multirow{2}{*}{ Data } & Kelas \\
\cline { 2 - 3 } & Eksperimen & Kontrol \\
\hline $\mathrm{N}$ & 34 & 34 \\
\hline Nilai Rata-rata & 68,6 & 54,9 \\
\hline Std. Deviasi & 11,89 & 12,06 \\
\hline Sig. Normalitas & 0,03 & 0,02 \\
\hline Sig. Homogenitas & 0,994 & \\
\hline $\begin{array}{l}\text { Uji Mann } \\
\begin{array}{l}\text { Whitney Asymp } \\
\text { Sig. (2-tailed) }\end{array}\end{array}$ & 0,006 & \\
\hline
\end{tabular}

Tabel di atas menunjukan jika data nilai posttes tidak berdisi normal akan tetapi bervasiansi homogen, artinya data tidak memenuri syarat untuk uji t- test $_{\text {indevendent }}$ oleh sebab itu uji yang dilakukan adalah uji Mann Whitney. Hasil uji Mann Whitney menunjukan nilai < 0,05, artinya ada perbedaan penguasaan konsep yang signifikan antara kelas kontrol dan kelas eksperimen. Belajar dengan menerapkan model project based learning memberikan pengalaman belajar yang berbeda kepada siswa, dimana dalam proses pembelajaran dengan menerapkan project based learning siswa dituntut untuk berperaan aktif untuk mencurahkan ide-ide yang dimilikinya serta mencurahkan seluruh perhatianya untuk mengumpulkan informasi untuk menyelesaikan proyek.

Menerapkan model project based learning menuntut siswa untuk menyelesaikan masalah dan mengatasi masalah yang terjadi di dunia nyata yang berhubungan dengan konsep yang diperoleh di sekolah, ketika siswa merasa apa yang dipelajarinya berhubungan dengan pengalaman sehari-hari siswa akan merasa termotivasi untuk mencari tahu lebih banyak. Hal tersebut seperti yang diungkapkan Klob (Abidin, 2009) mengungkapkan bahwa belajar; (a) Diverger yaitu belajar akan lebih baik dengan melihat dan mengalaminya (b) Assimilator yaitu bahwa belajar akan lebih baik dengan melihat dan berfikir. (c) Converger yaitu belajar akan lebih baik dengan berpikir dan melakukan. (d) Accomodator yaitu bahwa belajar akan mengalami dan melakukan. Dengan menerapkan project based learning seluruh aktivitas belajar dapat terfasilitasi. 
Pendapat tersebut sesuai dengan karekteristik pembelajaran poject based learning yang diungkapkan oleh Roopnarine dan Johnson (2011) memiliki tujuan untuk memberkan berbagai macam pengalaman di dalam kelas yang membentuk peran serta dalam proses demokratis, kerjasama, menyimak dan merespon ide satu sama lain, mengoordinasikan upaya dan kontribusi yang berbeda dari anggota dan seluruh subkelompok, menyelesaikan perselisihan meraih kesepahaman bagaimana memecahkan masalah dan menyelesaikan tugas dan sebagainya. Dengan menerapkan pembelajaran dengan $\mathrm{PjBL}$ seluruh cara belajar dapat terfasilitasi. Selain itu dua cara proses pemerolehan konsep yang diungkapkan Ausubel (Dahar, 2011) yaitu konsep diperoleh pada proses induktif dan asimilasi konsep, dengan menerapkan model project based learning kedua proses tersebut dapat terfasiliasi. Siswa memperoleh konsep secara induktif pada saat siswa melakukan observasi terhadap
Secara umum gambar 2 menunjukan peningkatan penguasaan konsep yang lebih baik pada kelas eksperimen. Pada indikator ke 2, 5 dan 9 kedua kelas mengalami peningkatan yang sama hal ini dikarenakan kedua kelas melakukan demonstrasi yang sama. Sedangkan pada indikator ke 10 dan ke 13 kelas kontrol mengalami peningkatan yang lebih baik daripada kelas eksperimen karena pada kelas kontrol siswa melakukan latihan untuk menghitung. Kelima belas

Tabel 3. Rerata N-gain tiap Aspek Kognitif

\begin{tabular}{|l|l|l|l|}
\hline \multirow{2}{*}{ Aspek Kognitif } & \multirow{2}{*}{ Indikator } & \multicolumn{2}{|l|}{ Rata-rata N-Gain } \\
\cline { 3 - 4 } & $\begin{array}{l}\text { Kelas } \\
\text { Eksperimen }\end{array}$ & $\begin{array}{l}\text { Kelas } \\
\text { Kontrol }\end{array}$ \\
\hline Mengingat & $1,2,3$, dan 4 & 0,5 & 0,3 \\
\hline Memahami & 5,6 dan 7 & 0,5 & 0,3 \\
\hline Mengaplikasikan & $8,9,10$ dan 11 & 0,4 & 0,3 \\
\hline Menganalisis & 12 dan 13 & 0,4 & 0,2 \\
\hline Mengevaluasi & 14 dan 15 & 0,6 & 0,2 \\
\hline
\end{tabular}

indikator yang disebutkan sebelumnya mewakili lima aspek kognitif pada taksonomi Bloom, dimana setiap aspek kognitf diwakili oleh dua hingga empat indikator. Untuk lebih jelas berikut ini tabel sebaran indikator berdasrkan aspek kognitif dan rerata n-gain tiap aspek kognitif pada kelas eksperimen dan kelas kontrol:

Berdasarkan tabel di atas menunjukan meskipun ada beberapa indikator yang

lingkungan sekitarnya dan apa yang dialaminya sehari-hari, dan proses pemerolehan konsep secara asimilasi diperoleh siswa pada saat siswa belajar disekolah. Berikut ini peningkatan penguasaan konsep siswa pada setiap indikator: mengalami peningkatan yang sama dan lebih baik pada kelas kontrol, akan tetapi jika dilihat rata-rata peningkatan pada setiap aspek kognitif menunjukan peningkatan yang lebih baik pada kelas eksperimen dibandingkan pada kelas kontrol.

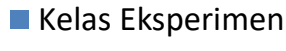

Kelas Kontrol

\section{Keterampilan Berpikir Kreatif Siswa yang Menerapkan Project Based Learning dan yang Bukan Project Based Learning}

Penjaringan data keterampilan berpikir kreatif mengunakan lima soal 
dimana setiap soal mengukur empat indikator. Adapun hasil pengolahan data pretest keterampilan berpikir kreatif siswa pada kedua kelas adalah sebagai berikut:

\section{Tabel 4. Hasil Pengolahan Data Pretest Keterampilan Berpikir Kreatif}

\begin{tabular}{|l|l|l|}
\hline \multirow{2}{*}{ Data } & Kelas \\
\cline { 2 - 3 } & Eksperimen & Kontrol \\
\hline N & 34 & 34 \\
\hline Nilai Rata-rata & 19,94 & 19,76 \\
\hline Std. Deviasi & 0,034 & 0,028 \\
\hline Sig. Normalitas & 0,66 & 0,09 \\
\hline Sig. Homogenitas & 0,06 & \\
\hline $\begin{array}{l}\text { Uji t-test }{ }_{\text {indevendent }} \\
\text { Sig. (2-tailed) }\end{array}$ & 0,97 \\
\hline
\end{tabular}

Berdasarkan tabel di atas menunjukan bahwa nilai keterampilan berpikir kreatif pada kelas eksperimen dan kelas kontrol, berdistribusi normal dan bervariansi homogen oleh sebab itu uji yang dilakukan untuk mengambil keputusan adalah uji Uji t-test ${ }_{\text {indevendent }}$ Sig. (2-tailed). Dari hasil uji$\mathrm{t}$ menunjukan bahwa tidak ada perbedaan yang signifikan keterampilan berpikir kreatif siswa pada kelas eksperimen dan kelas kontrol, oleh sebab itu selanjutnya yang dianalisis adalah data nilai posttest. Berikut ini tabel data hasil pengolahan nilai posttest penguasaan konsep siswa pada kelas eksperimen dan kelas kontrol:

\section{Tabel 5. Hasil Pengolahan Data Pretest Keterampilan Berpikir Kreatif}

\begin{tabular}{|l|c|c|}
\hline \multirow{2}{*}{ Data } & \multicolumn{2}{|l|}{ Kelas } \\
\cline { 2 - 3 } & Eksperimen & Kontrol \\
\hline N & 34 & 34 \\
\hline Nilai Rata-rata & 26,02 & 24,61 \\
\hline Std. Deviasi & 0,034 & 0,028 \\
\hline Sig. Normalitas & 0,69 & 0,06 \\
\hline Sig. Homogenitas & \multicolumn{2}{|c|}{0,20} \\
\hline $\begin{array}{l}\text { Uji t-test }{ }_{\text {indevendent }} \\
\text { Sig. (2-tailed) }\end{array}$ & \multicolumn{2}{|c|}{0,22} \\
\hline
\end{tabular}

Tabel di atas menunjukan bahwa data hasil posttest berdisistribusi normal dan bervariansi homogen, maka selanjutnya yang dilakukan uji-t untuk membuktikan hipotesis dari hasil hitung menunjukan nilai $0,22<0,05$ maka $H_{0}$ diterima, artinya tidak adanya perbedaan antara kemampuan berpikir kreatif siswa yang menerapkan pembelajaran dengan model project based learnig dengan yang bukan project based learning pada kelas kontrol. Ada beberapa hal yang menyebabkan rendahnya hasil tes keterampilan berpikir kreatif diantarnya; (1) tidak ada latihan secara kontinu yang dilakukan siswa untuk menguasai keempat aktivitas keterampilan berpikir kreatif. (2) keterbatasan waktu sehingga tidak ada pematauan terhadap aktivitas keterampilan berpikir kreatif siswa, karena siswa apabila sudah menyelesaikan tugas proyek sudah dianggap menguasai aktivitas-aktivitas keterampilan berpikir kreatif. (3) peran guru yang kurang maksimal melibatkan siswa untuk mengembangkan keterampilan berpikirnya, seharusnya guru mampu melibatkan siswa dalam pemikiran yang lebih tinggi seperti yang diungkapkan Vygotski (dalam Kuswana, 2011) yang menyatakan bahwa pendidik harus mencoba untuk membantu peserta didik terlibat dalam pemikiran tingkat yang lebih tinggi melalui bantuan terstruktur. Selain itu seperti yang diungkapkan Ayan (2002) banyak orang tidak mengembangkan daya kreatif mereka karena tidak diberi tahu cara memanfaatkan keterampilan kreatif alami ataupuan cara mengembangkan berbagai teknik. Berikut ini adalah grafik N-Gain pada setiap indikator pada kelas kontrol dan kelas eksperimen: 


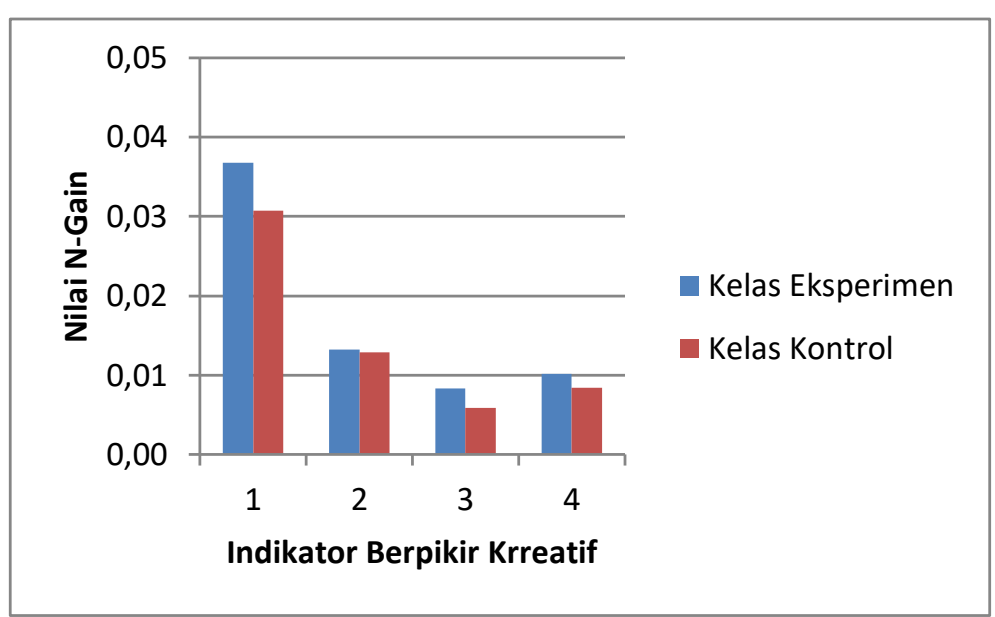

Gambar 3. Keterampilan Berpikir Kreatif Siswa pada Setiap Indikator

Grafik di atas menunjukan peningkatan keterampilan berpikir kreatif yang lebih baik pada kelas eksperimen, akan tetapi peningkatan tersebut tidaklah signifikan. Pada indikator pertama yaitu kelancaran (fluency) siswa telah mampu memberikan banyak jawaban akan tetapi jawbanyang diberikan kurang beragam atau tidak luwesan (flexibility). Indikator ke 3 keaslian (originality) dan penguraiaan (elaboration) kemampuan siswa masih sanyat rendah karena siswa tidak memiliki rasa percaya diri dan keberanian untuk memiliki jawaban yang berbeda dari rekan-rekanya.

\section{Kesimpulan dan saran}

Berdasarkan hasil temuan dan analisi yang telah dikemukakan pada bab sebelumnya, maka dapat disimpulkan:

Pertama, secara umum terdapat perbedaan peningkatan penguasaan konsep yang signifikan $(\mathrm{p}=0,00)$ antara kelas eksperimen yang belajar dengan menerapkan model project based learning pada proses pembelajarannya (rata-rata $\mathrm{N}$-gain $=0,477$ ) pada kategori sedang, dengan siswa yang belajar dengan menerapkan yang bukan project based learning (rata-rata N-gain = $0,290)$ pada kategori rendah.
Kedua, tidak ada perbedaan kemampuan berpikir kreatif antara kelas eksperimen dan kelas kontrol $(\mathrm{p}=0,22)$, dengan rata-rata $\mathrm{N}$-gain pada kelas eksperimen 0,075 sedangkan pada kelas kontrol sebesar 0,060 yang mana keduanya berada pada kategori rendah.

Berdasarkan kesimpulan penelitian, berikut ini disajikan beberapa implikasi yang bersesuaian, berikut ini:

Pertama, Pembelajaran dengan menerapkan model project based learning hendaknya menjadi alternatif pembelajaran bagi guru SD khususnya dalam pembelajaran IPA materi Daur Air untuk mengembangkan kemampuan berpikir kreatif dan penguasaan konsep siswa.

Kedua, untuk dapat memaksimalkan penguasaan konsep dan kemampuan berpikir keatif siswa, siswa harus dibiasakan: Pertama, membiasakan siswa membaca buku sebagai dasar untuk mengembangkan proyek. Kedua, memberikan kesempatan dan memfasilitasi siswa untuk mengembangkan kemampuan berpikirnya. Ketiga, membiasakan siswa belajar dengan model pembelajaran project based learning karena model ini dapat mengembangkan kreativitas dan meningkatkan penguasaan konsep siswa.

Ketiga, untuk mendapatkan hasil yang maksimal dalam penerapan model pembelajaran project based learning alokasi waktu harus dipertimbangkan dan pengawasan serta pendampingan guru dalam proses pembuatan proyek harus lebih ditingkatkan.

DAFTAR PUSTAKA

Anderson, L.W. \& Krathowhl, D.R. (2010). Kerangka Landasan Untuk Pembelajaran, Pengajaran dan Asesmen: Revisi Taksonomi Pendidikan Bloom. Terjemahan. Agung Prihantoro. Yogyakarta: Pustaka Pelajar. 
Andriana, E. (2012) Peningkatan Kemempuan Kerja Ilmiah Siswa dan Penguasaan Konsep Melalui Model Pembelajaran Berbasis Proyek. Tesis SPs UPI: Tidak Diterbitkan.

Ayan, E.J. (2002). Ways to Free your Creative Spirit and Find Your Great Ideas. Terjermahan. Ibnu Setiawaan. Bandung: Kaifa.

Aziz, S. (2014). Peningkatan Keterampilan Proses Sains dan Keterampilan Berpikir Kritis Melalui Pembelajaran Berbasis Proyek. Tesis SPs UPI: Tidak Dipublikasi.

Badan Standar Nasional Pendidikan. (2006). Standar Isi. Jakarta: BSNP.

Bellanca, J. (2012). Proyek Pembelajaran Yang Diperkaya. Terjemahan. Ririn Sjafriani. Jakarta: Indeks.

Brookhart, S. M. (2010). How To Assess Higer-order Thinking Skills In Your Classroom. Virginia USA: ASCD Alexandria.

Boss, S. \& Krauss, J. (2007). Reinventing Project-Based Learning: Your field guide to real-world projects in the digital age. Washington: International Society for technology in Education (ISTE)

Bundu, P. (2006). Penilaian Keterampilan Proses dan sikap Ilmiah dalam Pembelajaran Sains-SD. Jakarta: Depdiknas Direktorat Jendral Pendidikan Tinggi

Clark, AM. (2006). Changing Classroom Practice to Include the Project Approach. [Online] tersedia di: http://ecrp.uiuc.edu/v8n2/clark.html.

Diakses pada tanggal 20 Oktober 2014

Dahar, R.W. (2011). Teori-teori Belajar dan Pembelajaran. Jakarta: Erlangga.

Egenrieder, J.A. (2010) Facilitating Student Autonomy in Project-Based Learning to Foster Interes adn Resilience in STEM Education dan STEM careers. Virginia Tech. [Online] Diakses dari: http://washacadsci.org/journalartices.
Hamalik, O. (2003). Kurikulum dan Pembelajaran. Jakarta : Bumi Aksara Harlen, W. (2000). Teaching, Learning \& Assessing Science 5-12. London: SAGE Publication

Heryadi, D. (2012). Model Pembelajran Inkuiri Bebas yang Dimodifikasi untuk Meningkatkan Penguasaan Konsep Flida Statis dan Berpikir Kreatif Siswa SMA. Tesis SPs UPI: Tidak Diterbitkan.

Iskandar, M. S. (1997). Pendidikan IPA. Jakarta: Depdiknas.

Katz, L.G. Dan Chard, S.C. (1991). Engaging Children's Minds: The Project Approach. New jersey: Norwood

Kim, K. H. (2006). Struktur Laten dan Pengukuran Invarian Dari Skor Torrance: SAGE Juornal of Psicologi and Education assesment, Vol 66, Number 3, Pages 459-477.

Knoll, M. (1997). The Project Method: Its Vocational Education Origin and Internasional Development. Journal of Industrial Teacher Education, 34 (3), Pages 59-80.

Kuswana, W. S. (2011). Taksonomi Berpikir. Bandung: PT Remaja Rosdakarya.

Kwon, S.M., Dkk. (2014) Co-design of Interdisciplinary Projects as a Mechanism for School Capacity Growth. SAGE Journal of Improving Schools, Vol 17 (1), Page 54-71. [Online] Diakses dari: http://imp.sagepub.com/content/17/1 154

May, R. (1976). The Courage to Create (Apakah Anda Cukup Berani Untuk Kreatif). Terjemahan 2004. Jakarta: Teraju.

Munandar, U. (2009). Pengembangan Kretaivitas Anak Berbakat. Jakarta: Rineka Cipta

Roopnarine, J.L. dan Johnson, J.E. (2011). PAUD: Dalam Bergabai Pendekatan. Jakarta: Kencana Prenada Media Group. 
Santrock, J. W. (2010). Psikologi Pendidikan, Edisi Kedua. Jakarta: Kencana

Sugiyono. (2009). Model Penelitian Kuantitatif Kualitatif dan $R \& D$. Bandung: Alfabeta.

Suparno, P. (2005). Miskonsepsi dan Perubahan Konsep Pendidikan Fisika. Jakarta: Grasindo.

Supriadi, D. (1994). Kreativitas, Kebudayaan dan Perkembangan Iptek. Bandung: CV ALFABETA.

Thomas, J.W. (2000). A Review of Research of PBL. Vol.2. [Online] Diakses
http://www.bobpearlman.org/BestPr actices/PBLResearch.pdf.

Trianto. (2009). Mendesain Model Pembelajaran Inovatif-Progresif. Jakarta: Kencana.

The George Lucas Educational Foundation. (2007). Project-Based Learning Professional Development Guide. An overview of the Edutopia professional development guide for teaching how to use project-based learning in the classroom. [online]. Tersedia:http://www.edutopia.org/pr oject-based-learning-guide diunduh tgl 7 April 2014. 